\title{
PENDIDIKAN KARAKTER MENURUT KI HADJAR DEWANTARA DAN DRIYARKARA
}

\author{
Agam Ibnu Asa \\ Universitas Gadjah Mada Yogyakarta \\ Email: agamibnuasa@gmail.com
}

\begin{abstract}
Abstrak: Penelitian ini bertujuan untuk menganalisis pendidikan karakter menurut Ki Hadjar Dewantara dan Driyarkara dan relevansinya bagi pendidikan karakter di Indonesia. Penelitian ini merupakan penelitian kualitatif dengan bentuk studi pustaka. Objek material penelitian yaitu pemikiran pendidikan karakter Ki Hadjar Dewantara dan Driyarkara ditinjau dari perspektif aliran progresivisme. Metodenya dengan komparasi dua atau lebih filsuf atau aliran. Penelitian ini membandingkan dua pandangan tokoh, yaitu Ki Hadjar Dewantara dan Driyarkara tentang pendidikan Karakter. Hasil penelitian menunjukkan bahwa (1) pendidikan karakter Ki Hadjar Dewantara menekankan tiga instrumen dasar yaitu keluarga, perguruan, dan pergerakan pemuda; (2) Driyarkara menekankan satu kesatuan tunggal yaitu ayah-ibu-anak dalam pendidikan karakter dasar; dan (3) pendidikan karakter Ki Hadjar Dewantara dan Driyarkara apabila dikombinasikan akan relevan dengan pendidikan karakter di Indonesia.
\end{abstract}

Kata Kunci: pendidikan karakter, Ki Hadjar Dewantara, Driyarkara

\section{CHARACTER EDUCATION ACCORDING TO KI HADJAR DEWANTARA AND DRIYARKARA}

\begin{abstract}
This study aims to analyze character education according to Ki Hadjar Dewantara and Driyarkara and its relevance for character education in Indonesia. This research is a qualitative research with a form of literature study. The material objects of the study were the educational thoughts of the characters of Ki Hadjar Dewantara and Driyarkara, reviewed by the progressivism stream perspective. The method with a comparison of two or more philosophers or schools. This study compares two views of figures namely Ki Hadjar Dewantara and Driyarkara about Character education. The research shows the following results: (1) Ki Hadjar Dewantara's character education emphasizes three basic instruments namely family, college and youth movement; (2) Driyarkara emphasizes a single entity namely father-mother-child in basic character education; and (3) Education of Ki Hadjar characters Dewantara and Driyarkara when combined will be relevant to character education in Indonesia.
\end{abstract}

Keywords: character education, Ki Hadjar Dewantara, Driyarkara

\section{PENDAHULUAN}

Dewasa ini perkembangan di berbagai bidang kehidupan sangat pesat. Hal itu tidak lepas dari campur tangan manusia sebagai agen perubahan dalam kehidupan itu sendiri. Manusia mampu mencipta segala hal yang berkaitan dengan bidang ekonomi, sosial, politik, dan ilmu pengetahuan secara luar biasa. Hal tersebut dapat dilihat dari berbagai hasil ciptaan manusia seperti pesawat terbang, kapal laut, kereta api, dan bahkan menciptakan hewan yang berspesies baru. Kehebatan manusia tersebut ti- dak mudah ada begitu saja, melainkan adanya karena suatu pendidikan.

Secara sosiologis pendidikan merupakan sebuah upaya penerusan nilai-nilai kebudayaan dari generasi yang lebih tua kepada generasi yang lebih muda. Pendidikan dianggap sebagai sarana efektif proses sosial. Oleh sebab itu, pendidikan sering dijadikan sebagai agen perubahan sosial dalam sebuah masyarakat. Selain itu, Rijino menegaskan bahwa pendidikan juga ikut berpartisipasi dalam perubahan sosial itu sendiri, sehingga keduanya saling berhubungan secara timbal balik (Zainuddin, 
2008:24). Dengan pendidikan segala perkembangan ilmu pengetahuan dan sebagainya tersebut dimungkinkan terjadi karena adanya sebuah tranformasi nilai dalam sebuah peradaban manusia, yang membuat manusia untuk lebih progresif dalam menjalani kehidupan (Idris, 2017).

Seiring perkembangan zaman yang sangat pesat, pendidikan juga ikut mengalami perkembangan yang begitu pesat pula. Kecanggihan teknologi dan informasi membuat dunia pendidikan semakin modern dan menyesuaikan dengan globalisasi. Persoalan yang muncul dengan perubahan zaman ini, yaitu merosotnya karakter generasi muda yang semakin memprihatinkan karena dianggap menyimpang jauh dari nilai-nilai yang hidup di Indonesia.

Rachman (Ningrum, 2015:19) juga menambahkan bahwa remaja modern saat ini mempunyai kecenderungan dan permisif terhadap hubungan seks pranikah. Pusat data Badan Koordinasi Keluarga Berencana Nasional (BKKBN) tahun 2007 memaparkan hasil penelitian yang dilakukan oleh Damayanti untuk disertasinya pada Fakultas Ilmu Kesehatan Masyarakat, Universitas Indonesia menunjukkan bahwa dari 100 orang siswa, 5 di antaranya pernah melakukan hungan seks di luar nikah. 119 sekolah di lima daerah di Jakarta dan 8941 siswa sekolah menengah atas ikut ambil bagian dalam penelitian ini. Selanjutnya survei yang dilakukan oleh BKKBN di 33 provinsi di Indonesia pada tahun 2008 menyebutkan bahwa sekitar 63\% dari remaja terlibat dalam hubungan seks pranikah dan 21\% remaja putri melakukan aborsi. Kemudian, data mengejutkan datang dari Dinas Kesehatan tahun 2009 menunjukkan bahwa remaja-remaja di empat kota besar yakni Medan, Jakarta Pusat, Bandung, dan Surabaya mempunyai teman yang berhubungan seks sebelum menikah sebesar $35.9 \%$. Sementa- ra itu, para responden dalam data ini juga sudah melakukan hubungan seks pra nikah sebesar 6.9\% (Ningrum, 2015:19).

Selain itu, survey yang diadakan oleh Komisi Nasional Perlindungan Anak pada bulan Januari - Juni 2010 di kota-kota besar di Indonesia yang melibatkan 4500 siswa sekolah pertama dan menengah memperlihatkan bahwa 62.75 siswa perempuan sudah tidak perawan lagi. Tentu saja fenomena ini sangatlah mengkhawatirkan karena pada pundak remaja inilah harapan itu disematkan, mengingat remaja sebagai generasi penerus bangsa, dan harapan itu akan memudar apabila remaja terjerumus dalam pergaulan bebas dan seks bebas (Ningrum, 2015:19).

Tentu saja berbagai problem kenakalan remaja tersebut berkaitan erat dengan bagaimana pendidikan karakter dalam sebuah institusi sekolah itu berlangsung. Karena jika pendidikan karakter benar-benar berhasil diterapkan, kenakalan remaja sebagaimana sudah dicontohkan tersebut setidaknya dapat diminimalisasi. Oleh sebab itu, penulis tertarik mengkaji persoalan pendidikan karakter menurut dua pemikir besar terkait dengan pendidikan yang ada di Indonesia, yaitu Ki Hadjar Dewantara dan Driyarkara. Setidaknya dari kedua tokoh ini nantinya akan didapatkan sebuah pemahaman tentang konsep pendidikan karakter menurut dua tokoh tersebut dan kemudian dikaitkan dengan pendidikan karakter di Indonesia.

Ki Hadjar Dewantara dan Driyarkara adalah dua tokoh yang memiliki pandangan terkait dengan pendidikan. Pendidikan karakter dalam hal ini dapat dicapai dengan beberapa cara. Ki Hadjar Dewantara (Suparlan, 2015) menjelaskan dalam konsep pendidikan yang harus berfokus pada Tri Pusat Pendidikan: (1) pendidikan keluarga; (2) pendidikan dalam alam pergu- 
ruan; dan (3) pendidikan dalam alam pemuda atau masyarakat. Menurut Driyarkara pendididikan sebagai hominisasi dan humanisasi atau memanusiakan manusia dan hominisasi sebagai proses memanusiakan manusia pada umumnya (Aziz, 2016: 136). Kedua pandangan ini nantinya akan penulis tinjau dengan aliran Progresivisme, dengan pandanganya yang menganggap bahwa manusia mempunyai kemampuankemampuan yang wajar dan dapat menghadapi dan mengatasi masalah-masalah yang bersifat menekan atau mengancam manusia itu sendiri (Barnadib, 1982:28).

Dengan menganalisis menggunakan progresivisme tersebut kiranya dua pandangan tokoh tersebut nantinya ditemukan sebuah benang merah yang membuat kedua konsep tersebut memiliki sebuah kesamaan, yaitu terkait dengan tujuan pendidikan karakter itu sendiri dan nantinya akan direlevansikan dengan konsep pendidikan karakter di Indonesia.

Penelitian ini kiranya penting sebagai upaya mendapatkan sebuah pemahaman baru terkait dengan pendidikan karakter di Indonesia dengan sudut pandang konsep pendidikan Ki Hadjar Dewantara dan Driyarkara. Melihat semakin merosotnya karakter siswa didik sebagaimana dikatakan Husaini (2010:1) bahwa munculnya gagasan program pendidikan karakter di Indonesia, bisa dimaklumi karena selama ini proses pendidikan dirasa belum berhasil membangun manusia Indonesia yang berkarakter. Bahkan, banyak yang menyebut, pendidikan telah gagal, karena banyak lulusan sekolah atau sarjana yang piawai dalam menjawab soal ujian, berotak cerdas, tetapi mental dan moralnya lemah.

Adapun beberapa problem yang akan dicoba dijawab dalam penelitian ini di antaranya sebagai berikut. Pertama, tentang bagaimana pendidikan karakter menurut
Ki Hadjar Dewantara dan Driyarkara? Kedua, bagaimana pandangan aliran progresivisme? Ketiga, bagaimana tinjauan progresivisme terhadap komprasi pendidikan karakter Ki Hadjar Dewantara dan Driyarkara?

\section{METODE}

Penelitian ini merupakan penelitian komparatif. Penelitian ini membandingkan dua atau lebih filsuf atau aliran. Penelitian ini membandingkan dua pandangan tokoh yaitu Ki Hadjar Dewantara dan Driyarkara tentang pendidikan karakter (budi pekerti). Nantinya penelitian ini akan mengarah pada pencarian persamaan dan perbedaan pandangan pendidikan karakter Ki Hadjar Dewantara dan Driyarkara, kemudian mencari kelebihan dan kekurangan pandangan dua tokoh tersebut dan menarik relevansinya bagi pendidikan di Indonesia.

Penelitian ini menggunakan data yang diperoleh melalui penelusuran kepustakaan yang terkait dengan tema objek material dan objek formal. Data tersebut dikategorikan menjadi dua sumber pustaka, yaitu pustaka primer dan pustaka sekunder. Pustaka primer yaitu data utama yang digunakan oleh peneliti sebagai sumber acuan, meliputiunsur-unsuryang berkaitan dengan objek material yaitu pemikiran pendidikan karakter Ki Hadjar Dewantara dan Driyarkara, juga objek formal yaitu pandangan aliran progresivisme yang semuanya termuat dalam buku-buku, hasil-hasil penelitian, dan juga jurnal.

Penelitian ini merupakan penelitian komparatif, penulis memilih beberapa metode sebagai berikut. Deskripsi, yang berfungsi menampakkan kesamaan dan perbedaan kedua konsep baik yang tampak dalam istilah, pendekatan, argumentasi, segi perhatian, maupun yang lebih mendalam dalam asumsi dasar, orientasi berpikir. Eva- 
luasi kritis, untuk membandingkan kekuatan dan kelemahan masing-masing pandangan. Setelah itu dilakukan evaluasi dengan membandingkan dua pandangan yang ada (Bakker \& Zubair, 1990:84).

Interpretasi, yakni masing-masing pandangan atau visi yang dibandingkan dipahami menurut warna dan keunikanya sendiri-sendiri. Dari awal diberi tekanan pada segi-segi yang relevan bagi tematema atau masalah yang dikomparasikan pada mereka, dan pada asumsi-asumsi yang melandasi mereka (Bakker \& Zubair, 1990:85). Holistik, yakni semua istilah dilihat dalam rangka keseluruhan visi naskah dan seluruh pandangan dan perkembangan pikiran pengarang mengenai manusia, dunia, dan Tuhan (Bakker \& Zubair, 1990:86).

Komparasi, yakni perbandingan dapat dibuat setelah masing-masing pandangan tokoh diuraikan secara lengkap. Perbandingan juga bisa dimulai dengan menguraikan pandangan tokoh terlebih dahulu sambil menguraiakan bisa sekaligus memberikan perbandingan serta dapat diketemukan model perbandingan ketiga dengan menekankan pada aspek tertentu atau justru menyeluruh pada kedua tokoh (Bakker \& Zubair, 1990: 87).

\section{HASIL DAN PEMBAHASAN \\ Pendidikan Karakter Menurut Ki Hadjar Dewantara dan Driyarkara}

Muslich menegaskan bahwa karakter merupakan nilai-nilai perilaku manusia yang berhubungan dengan Tuhan Yang Maha Esa, diri sendiri, sesama manusia, lingkungan, dan kebangsaan yang terwujud dalam pikiran, sikap, perasaan, perkataan, dan perbuatan berlandaskan normanorma agama, hukum, tata krama, budaya, dan adat istiadat. Pendidikan karakter adalah suatu sistem penanaman nilai-nilai ka- rakter kepada warga sekolah yang meliputi komponen pengetahuan, kesadaran atau kemauan, dan tindakan untuk melaksanakan nilai-nilai tersebut, baik terhadap Tuhan Yang Maha Esa (YME), diri sendiri, sesama, lingkungan, maupun kebangsaan sehingga menjadi manusia yang utuh atau insan kamil (Ningsih, 2015: 56 ).

Karakter dapat dibentuk salah satunya dengan pendidikan. Pendidikan merupakan perbuatan fundamental karena pendidikan mengubah dan mengonstruksi perbuatan manusia, karena mendidik itu memanusiakan manusia (muda), karena mendidik itu perbuatan hominisasi dan humanisasi. Perbuatan yang membuat manusia menjadi manusia, sudah selayaknya diakui dan dikatakan sebagai perbuatan fundamental (Driyarkara, 1980:87). Karena dengan hal itu manusia akan tetap memiliki budi pekerti yang luhur ketika sudah ditanamkan dari semenjak muda.

Pendidikan karakter mengarahkan pada cara berpikir dan perilaku dari siswa yang nantinya akan menjadi tulang punggung bangsa. Karakter termanifestasi dalam sifat dan perbuatan untuk selaras dengan budaya bangsa Indonesia yang selama ini telah melekat. Pengaruh modernisasi dan globalisasi yang memberikan banyak warna dalam kehidupan remaja memang harus dibentengi dengan pembelajaran karakter. Boleh dikatakan bahwa pendidikan karakter adalah usaha untuk penanaman nilai-nilai pada siswa melalui berbagai macam cara untuk menjadikan mereka sebagai individu yang berguna bagi masyarakat, bangsa, dan negara. Implementasi dari pendidikan karakter di Indonesia bersumber pada Pancasila yang selama ini menjadi dasar penting. Adapun pengembangan dari pendidikan karakter dipandu dengan buku dari pemerintah, yang selanjutnya diolah lebih mendalam oleh 
sekolah masing-masing yang menguasai keadaan secara langsung. Maka dari itu, tidak mengherankanjika implementasi pendidikan karakter di tiap-tiap sekolah memiliki wacana dan praktik yang berbedabeda karena keadaan di tiap sekolah juga berbeda (Ningsih, 2015:3).

Ki Hadjar Dewantara dan Driyarkara dalam hal ini merupakan tokoh di Indonesia yang memiliki gagasan tentang pendidikan karakter yang cukup mendasar.

\section{Biografi Ki Hadjar Dewantara}

Ki Hadjar Dewantara terlahir dengan nama Raden Mas Soewardi Soeryaningrat di Yogyakarta tepatnya pada tanggal 2 Mei 1889 di lingkungan kraton Yogyakarta. Raden Mas Soewardi Soeryaningrat saat berusia 40 tahun berganti nama menjadi Ki Hadjar Dewantara. Mulai saat itu ia tidak menggunakan nama kebangsawanan di depan namanya. Hal itu supaya ia dapat dekat dengan rakyat baik secara fisik maupun hatinya. Perjalanan hidupnya benarbenar diwarnai perjuangan dan pengabdian demi kepentingan bangsanya (Suroso, 2011: 47-48).

KiHadjar Dewantara menamatkan sekolah dasar di ELS (Sekolah Dasar Belanda) kemudian melanjutkan ke Stovia (Sekolah Dokter Bumiputera), tetapi tidak sampai tamat karena sakit. Ia juga sempat menjadi wartawan dan aktif mengikuti organisasi sosial dan politik. Pada tahun 1908 ia aktif di seksi propaganda Budi Oetomo untuk menyosialisasikan dan menggugah kesadaran masyarakat Indonesia pada waktu itu mengenai pentingnya persatuan dan kesatuan dalam berbangsa dan bernegara. Bersama Douwes Dekker dan dr. Cipto Mangoenkoesoemo, ia mendirikan Indische Partij (partai politik pertama yang beraliran nasionalisme Indonesia) pada tanggal 25
Desember 1912 yang bertujuan Indonesia merdeka (Suroso, 2011:48).

Perjalanan karier Ki Hadjar Dewantara cukup panjang, selain pada keseriusannya mencurahkan perhatian pendidikan di Tamansiswanya, ia juga tetap rajin menulis. Namun, tema tulisanya beralih dari nuansa politik ke pendidikan dan kebudayaan berwawasan kebangsaan. Tulisanya berjumlah ratusan buah. Melalui tulisantulisan itulah ia berhasil meletakkan dasardasar pendidikan nasional bagi bangsa Indonesia. Setelah zaman kemerdekaan, Ki Hadjar Dewantara pernah menjabat sebagai MenteriPendidikan, Pengajaran, dan Kebudayaan yang pertama. Nama Ki Hadjar Dewantara tidak hanya diabadikan sebagai seorang dan tokoh pahlawan pendidikan yang bergelar Bapak Pendidikan Nasional yang oleh karenya pada tanggal 2 Mei yang merupakan tanggal kelahiranya dijadikan hari pendidikan nasional, akan tetapi ia juga ditetapkan sebagai pahlawan pergerakan nasional melalui keputusan presiden RI No. 305 Tahun 1959, tanggal 28 November 1959. Penghargaan lain yang diterimanya adalah gelar Doctor Honoris Causa dari Universitas Gadjah Mada pada tahun 1957. Dua tahun setelah mendapat gelar itu, ia meninggal dunia pada tanggal 28 April 1959 di Yogyakarta dan dimakamkan di Yogyakarta (Suroso, 2011: 51).

\section{Pendidikan Budi Pekerti (Karakter) Ki Ha- djar Dewantara}

Ki Hadjar Dewantara menjelaskan bahwa budi pekerti atau watak yaitu bulatnya jiwa manusia, yang dalam bahasa asing disebut "karakter" sebagai jiwa yang berasas hukum kebatinan. Orang yang telahmempunyai kecerdasan budi pekerti senantiasa memikirkan dan merasakan serta memakai ukuran, timbangan dan dasar yang pasti dan tetap. Itulah sebabnya tiap- 
tiap orang itu dapat dikenal wataknya dengan pasti. Karena watak atau budi pekerti bersifat tetap dan pasti buat satu-satunya manusia, sehingga dapat dibedakan orang yang satu dengan yang lain. Budi pekerti, watak, atau karakter, adalah bersatunya gerak pikiran, perasaan dan kehendak atau kemauan, yang lalu menimbulkan tenaga. Budi berarti "fikiran, perasaan, kemauan" dan pekerti artinya "tenaga". Jadi, budi pekerti adalah sifat jiwa manusia, mulai dari angan-angan hingga terjelma sebagai tenaga (Tamansiswa, 2013:25).

Atas dasar hal tersebut pendidikan karakter sangatlah dibutuhkan dalam rangka menciptakan para generasi penerus bangsa yang memiliki budi pekerti atau karakter yang kuat, supaya nantinya dalam kehidupan berbangsa dan bernegara mereka mampu bersikap sesuai prinsip luhur yang mereka pegang. Mereka tidak akan goyah pada suatu hal yang kiranya akan membuat mereka jatuh pada jurang kesesatan, yang justru nantinya akan merugikan mereka sendiri.

Ki Hadjar Dewantara mengatakan bahwa dengan adanya budi pekerti, setiap manusia berdiri sebagai manusia merdeka, yang dapat menguasai dan memerintah diri sendiri. Itulah manusia yang beradab dan itulah tujuan pendidi kan dalam garis besarnya. Pada dasarnya pendidikan berkuasa untuk mengalahkan dasar-dasar jiwa manusia, baik dalam arti melenyapkan dasar-dasar yang jahat dan memang dapat dilenyapkan maupun mengurangi atau menutupi tabiat-tabiat yang tak dapat lenyap sama sekali, karena bersatu dengan jiwa.

Budi pekerti seseorang dapat mewujudkan sifat kebatinan seseorang dengan pasti dan tetap. Perlu ditegaskan bahwa ada dua budi pekerti seseorang yang sama sekaligus. Seperti halnya keadaan dengan roman muka manusia yang tidak ada yang sama. Meskipun begitu orang dapat membagi-bagi budi pekerti manusia menjadi beberapa macam atau jenis dengan maksud supaya orang dapat mempunyai ikhtisar tentang garis-garis atau sifat-sifat watak orang yang umum (Tamansiswa, 2013:25).

Pendidikan karakter menurut Ki Hadjar Dewantara dapat ditempuh dengan Sistem Trisentra yaitu tiga tempat pergaulan yang menjadi pusat pendidikan. Di dalam kehidupan anak-anak ada tiga tempat pergaulan yang menjadi pusat pendidikan yang amat penting baginya yaitu alam keluarga, alam perguruan, dan alam pergerakan pemuda. Pertama, pendidikan akan senpurna apabila tidak hanya disandarkan pada sikap dan tenaga si pendidik, akan tetapi juga harus beserta suasana yang sesuai dengan maksud pendidikan. Kemudian yang kedua yaitu menghidupkan, menambah dan menggembirakan perasaan kesosialan tidak akan terlaksanan jika tidak didahului pendidikan diri (pendidikan individual) karena inilah dasar pendidikan budi pekerti yang akan dapat menimbulkan rasa kemasyarakatan dan rasa kesosialan.

Alam keluarga adalah pusat pendidikan yang pertama dan yang terpenting, oleh karena sejak timbulnya adab-kemanusiaan hingga kini, hidup keluarga itu selalu mempengaruhi tumbuhnya budi pekerti dari tiap-tiap manusia. Karena di lingkungan keluargalah segala hal asali berasal, sehingga banyak pula pengaruh yang dihasilkan dalam keluarga terhadap budi pekerti anak. Alam perguruan adalah pusat pendidikan yang teristimewa, karena perguruan berkewajiban mengusahakan kecerdasan pikiran (kecerdasan intelektual) beserta memberikan ilmu pengetahuan (balai-wiyata). Sedangkan alam pemuda adalah pergerakan pemuda yang pada zaman kini terlihat sudah tetap adanya, yang harus diakui dan digunakan untuk menyo- 
kong pendidikan di alam keluarga dan perguruan (sekolah) (Tamansiswa, 2013:75).

Ki Hadjar Dewantara juga menambahkan bahwa, setiap pusat pendidikan itu harus tau kewajibanya sendiri-sendiri dan mengakui haknya pusat-pusat lainya. Keluarga merupakan ujung tombak dalam membentuk dasar budi pekerti dan perilaku sosial. Perguruan sebagai balai-wiyata, yaitu usaha mencari dan memberikan ilmu pengetahuan, di samping pendidikan intelek. Pergerakan pemuda, sebagai daerah merdekanya kaum pemuda atau "kerajaan pemuda" untuk melakukan penguasaan diri, yang amat diperlukan untuk pembentukan watak atau karakter.

\section{Biografi Driyarkara}

Prof. Dr. Nicolaus Driyarkara SJ. Lahir di Kedunggubah, Kaligesing, Purworejo, 13 Juni 1913 dan meninggal di Girisonta, Ungaran, Jawa Tengah, 11 Februari 1967 pada umur 53 tahun. Ajaran pokok Driyarkara yaitu "Manusia adalah kawan bagi sesama". Manusia adalah rekan atau teman bagi sesamanya di dunia sosialitas ini (homo homini socius). Pikiran homo homini socius ini ditaruh untuk mengkritik, mengoreksi, dan memperbaiki sosialitas preman; sosialitas yang saling mengerkah, memangsa, dan saling membenci dalam homo homini lupus (manusia adalah serigala bagi manusia lain). Sampai tahun 1951 nama Driyarkara tidak dikenal. Hampir seluruh waktunya ia gunakan untuk studi secara intensif. Catatan harian yang ditulisnya sejak 1 Januari 1941 sampai awal tahun 1950 tidak pernah lepas dari persoalan aktualmendesak yang dihadapi manusia, khususnya rakyat Indonesia (Pratyanto, 2017).

Karya publik awal tulisannya tidak langsung filosofis. Karya awalnya berupa catatan ringan dalam bahasa Jawa yang dimuat majalah Praba, sebuah mingguan berbahasa Jawa yang terbit di Yogyakarta yang disusul kemudian dengan Warung Podjok dengan nama samaran Pak Nala. Terbitnya majalah Basis tahun 1951 membuka peluang Driyarkara memperkenalkan ide-idenya ke masyarakat, mulanya dengan nama Puruhita, kemudian dengan nama lengkap Driyarkara. Cara penyajiannya bergaya percakapan, setapak demi setapak membawa pembaca ke permenungan filosofis. Saat mengasuh Basis, Driyarkara diserahi tugas menjadi Dekan Perguruan Tinggi Pendidikan Guru Sanata Dharma, embrio IKIP Sanata Dharma. Pidato pertanggungjawabannya tentang kepentingan pendidikan guru memperoleh tanggapan luas, dan sejak saat itu (1955) selain dikenal sebagai filsuf, ia juga dikenal sebagai seorang ahli pendidikan. Lewat tulisan, pidato, ceramah, dan kuliahnya, Driyarkara memberikan pencerahan proses pencarian jati diri bangsa. Misalnya, ketika gerakan mahasiswa marak pada tahun 1966, ialah pembela pertama hak mahasiswa dan pelajar untuk demonstrasi. Di tengah keadaan kritis dan buntu-mentok, ia tampil dengan gagasan menerobos lewat pemberian makna (Pratyanto, 2017).

Riwayat Pendidikan dan Karier Driyarkara seperti berikut.

- Pada tahun 1952, ia mendapat gelar Doktor bidang Filsafat di Universitas Gregoriana dengan disertasi mengenai Nicolas Malebrance.

- 1941-1942, ia sudah mengajar sebagai dosen di Girisonta.

- 1943-1946, ia menjadi pengajar filsafat di Seminari Tinggi Yogyakarta.

- 1952-1958, setelah Ph.D., ia menjadi dosen filsafat di Yogyakarta.

- 1960-1967, ia menjadi Guru Besar Luar Biasa di Fakultas Psikologi, Universitas Indonesia. 
- 1961-1967, ia menjadi dosen di Universitas Hasanudin, Ujung Pandang (Makassar).

- 1962-1967, ia menjadi anggota MPRS.

- 1963-1964, ia menjadi dosen tamu di Universitas St. Louis, Amerika Serikat.

- 1965-1967, ia menjadi anggota DPA RI.

\section{Pendididikan Karakter Driyarkara}

Driyarkara (1980:79) memberikan gambaran bagaimana aktivitas mendidik karater itu. Mendidik pada dasarnya juga mempunyai gambaran pada anak didik. Jadi, seolah dalam hal ini ada perbandingan. Anak didik dilihat sebagai manusia dalam perjalan ke kemanusiaannya. Dalam menjelaskan pandangan ini, Ia mengajak untuk membayangkan anak yang berumur 4 atau 5 tahun. Anak itu belum bisa menempatkan diri dalam dunia manusia. Dia baru mulai memasuki dunia itu. Pendidik yang melihat yang demikian ini kiranya mengerti bahwa tingkah laku anak selalu bisa tidak pada tempatnya. Anak selalu dilihat sebagai manusia yang berusaha bertindak sesuai dengan kemanusiaanya, tetapi belum sampai. Dalam posisi yang demikian pendidik juga diharuskan memiliki pandangan manusia seperti yang diharuskan.

Gambaran ini konkret menurut kebudayaan yang ada, misalnya manusia harus sopan dengan cara tertentu. Maka dalam perbandingan ini pendidik harus menangkap bagaimana si anak berbuat, jika ia hendak memenuhi kodratnya sebagai manusia, sesuai dengan kemampuan si anak itu. Si anak harus "memanusia" sebelum sebagai manusia "purnawarman". Tetapi sesuai dengan umurnya si anak itu belum mandiri. Maka peran pendidik perlu supaya anak dapat bertindak sedemikian rupa, hingga anak bertindak seperti yang dimaksud itu (Driyarkara, 1980:79).
Driyarkara mengatakan bahwa pendidik bertindak, anak bertindak, tetapi dua tindakan ini seolah-olah mengalir memasuki anak, dan anak menjelmakan perbuatan itu terhadap dirinya sendiri, menurut ukuran anak. Maka perbuatan anak itu sesuai dengan taraf insani menjadi human. Si anak dalam hal ini memanusia dan sekaligus pendidikan memanusiakanya, si anak tidak pasif. Ia berbuat seperti ibunya berbuat, ia mengidentfikasikan diri dengan ibunya, dan dalam identifikasi ini ia merasa berbuat yang sebenarnya. Ibu (pendidik) seolah menyelam dalam anaknya, bukan untuk menghilangkan perbuatan anaknya, melainkan sebaliknya supaya anak berbuat. Ia mengidentifikasikan diri dengan anaknya supaya anak menemukan dirinya.

Misalnya, ketika anak harus mengatakan sesuatu. Anak belum bisa, meskipun sedikit demi sedikit mengerti yang harus dikatakan. Anak belum mengerti kata-kata yang harus digunakan, belum mengerti cara membuat kalimat yang diperlukan. Maka ibulah yang memberi kata-kata, ibulah yang mengucapkan kalimat, bahkan dengan cara kekanak-kanakan. Si anak kemudian menirunya untuk mengucapkan kata-kata itu. Dan kalimat itu menjadi kalimat dari anak itu. Dalam contoh ini ibu memanusiakan anak dengan membuatnya "membahasa".

Pada paparan ini selalu dibayangkan anak masih kecil. Tetapi dengan perubahan seperlunya isi gambaran ini berlaku juga bagi bagi anak didik yang sudah lebih besar. Makin besar si anak, makin mulai berdikarilah dia, sehingga semakin berbuat sendiri. Tetapi selama berposisi sebagai anak didik, selama belum bisa bertanggung jawab sendiri, belum cukup pertumbuhanya sehingga mempunyai otonomi, selama itu juga ia masih berada pada proses pe-manusia-an (Driyarkara, 1980:80). 
Hominisasi dan humanisasi sebagai proses pendidikan karakter. Proses hominisasi (Driyarkara, 1980:82) yaitu proses kemenjadian manusia secara alami, artinya proses terjadinya manusia mulai dari kandungan ibunya, yang kemudian berkembang mendapat bentuk manusia dalam porsi kecil dan lahir menjadi bayi, meskipun sebagai bayi manusia barun itu toh tetap belum bisa bertindak sebagai manusia. Ia perlu tumbuh dan berproses untuk sampai pada kemanusiaanya. Manusia bukanlah makhluk biologis, melainkan seorang pribadi atau person, seorang subjek, artinya mengerti diri, menempatkan diri dalam situasinya, mengambil sikap dan menentukan dirinya: nasibnya ada di tangan sendiri.

Hominisasi tidak pernah lepas dari humanisasi. Humanisasi biasanya merujuk pada perkembangan yang lebih tinggi. Jikalau hanya mengingat arti kata human, berarti sesuai dengan kodrat manusia, jadi sama denga insani atau manusiawi. Tingkat humanisasi merupakan tingkat kebudayaan yang lebih tinggi. Manusia itu mengangkat alam menjadi alam manusiawi. Tanah menjadi ladang, tumbuh-tumbuhan menjadi tanaman, barang-barang materi menjadi alatnya, rumahnya, pakaianya (Driyarkara, 1980: 83). Sebagai contoh humanisasi, dalam lingkungan tani anak kecil sudah sering ikut ke sawah atau ladang. Semula hanya untuk ikut saja, untuk melihat. Lama-lama anak ikut kerja sedikit demi sedikit. Kelak malahan mendapat tugas kecil-kecil, dalam hal ini apa yang dilihat? Proses pemanusiaan anak. Tetapi dalam bentuk yang tertentu. Dalam tindakan ayah itu termuat tindakan bahwa manusia harus menjadi pembuat produksi (Driyarkara, 1980:87). Selain itu, dapat dimaknai juga bahwa dalam hal ini humanisasi merupakan proses pendidikan karakter yang paling dasar pada anak, yang nantinya akan berpengaruh pada kehidupan anak kelak di masyarakat dan negara.

Dari uraian di atas dapat ditarik sebuah pemahaman bahwasanya intisari mendidik ialah pe-manusia-an manusia-muda yaitu hominisasi dan humanisasi. Selain itu, teranglah mengapa pendidikan atau mendidik disebut perbuatan fundamental atau yang mengubah, menentukan dan mengkonstruksi hidup manusia. Sebab mendidik itu memanusiakan manusia (muda), karena mendidik itu hominisasi dan humanisasi. Perbuatan yang menyebabkan manusia menjadi manusia, sudah sewajarnya diakui dan dinyatakan sebagai perbuatan fundamental (Driyarkara, 1980: 87) karena pada proses ini pendidikan karakter telah terjadi, yaitu penanaman dan pembentukan sikap dasar budi pekerti anak.

Pendidikan karakter yang paling fundamental dapat dibentuk dalam kesatuan tri tunggal yaitu ayah-ibu-anak. Bagi manusia berketurunan tidak hanya berarti melahirkan secara biologis. Dengan hanya melahirkan ia belum menurunkan secara insani. Melahirkan secara bilologis harus dilanjutkan dengan melahirkan secara insani, dalam hal ini membawa anak ke tingkat manusia dan ini berarti pendidikan karakter dasar. Untuk tugas ini ayah dan ibu seolah bersedia lahir dan batin maka timbulah kesatuan antara anak dan orang tua, yang tidak bisa diganti. Jadi, pendidikan adalah hidup bersama dalam kesatuan tritunggal ayah-ibu-anak, yang di situ terjadi pe-manusiaan-anak, dengan mana dia berproses untuk akhirnya memanusia sendiri sebagai manusia purnawarman (Driyarkara, 1980:129). Pendidikan karakter dalam hal ini terjadi dalam proses tritunggal itu dari menyatunya ayah-ibu-anak sampai pada taraf purnawarman, yaitu di mana karakter anak terbentuk ia mampu mema- 
hami dirinya sendiri sebagaimana ia menjadi manusia pada umumnya yang bebas dan bertanggung jawab.

\section{Pandangan Progresivisme}

Aliran progresivisme mengakui dan berusaha mengembangkan asas progresivisme dalam semua realita kehidupan, agar manusia bisa survive menghadapi tantangan hidup. Aliran ini disebut juga instrumentalisme karena beranggapan bahwa kemampuan intelegensi manusia sebagai alat untuk hidup, untuk kesejahteraan dan untuk mengembangkan kepribadian manusia. Selain itu, aliran ini disebut juga sebagai environmentalisme, karena aliran ini menganggap lingkungan hidup itu mempengaruhi pembinaan kepribadian (Jalaludin dan Idi, 2012: 24; Fadlillah, 2017).

Aliran progresivisme telah memberikan sumbangan yang besar terhadap dunia pendidikan pada abad ini. Aliran ini telah meletakkan dasar-dasar kemerdekaan dan kebebasan kepada anak didik. Anak didik diberikan kebebasan baik secara fisik maupun dalam hal cara berpikir, guna mengembangkan bakat dan kemampuan yang terpendam di dalam dirinya tanpa terhambat oleh orang lain (Ali, 1990:146). Filsafat progresivisme tidak sepakat dengan pendidikan yang otoriter. Sebab pendidikan yang otoriter akan mematikan tunas-tunas para pelajar untuk hidup sebagai pribadi yang gembira menghadapi pelajaran dan mematikan daya kreasi baik secara fisik maupun psikis anak didik (Jalaluddin dan Idi, 2012:90; Fadlillah, 2017)

Selain hal di atas filsafat progresivisme memandang kebudayaan sebagai hasil budi manusia yang dikenal sepanjang sejarah sebagai kepunyaan manusia yang tidak beku, melainkan selalu dinamis. Maka pendidikan sebagai usaha manusia yang merupakan refleksi dari kebudayaan harus seji- wa dengan kebudayaan tersebut (Barnadib, 1992:24; Fadlillah, 2017). Filsafat pogresivisme mempunyai konsep bahwa anak didik memiliki akal dan kecerdasan yang oleh karena itu menjadi potensi kelebihan manusia dibanding dengan makhluk lain. Dengan potensi yang bersifat kreatif tersebut anak dididik mempunyai bekal untuk menghadapi dan memecahkan problem-problemnya (Jalaluddin dan Idi, 2012:90-91; Fadlillah, 2017).

Barnadib (1992:25) menjelaskan bahwa progresivisme menghendaki pendidikan yang progresif. Tujuan pendidikan diartikan sebagai rekontruksi pengalaman yang secara terus-menerus. Pendidikan bukan hanya menyampaiakan pengetahuan kepada anak didik saja, melainkan yang paling utama adalah melatih kemampuan anak berpikir secara ilmiah. Semua itu dilakukan dengan pendidikan supaya orang mengalami progress. Dengan demikian, orang akan bertindak dengan intelegensi sesuai dengan tuntutan dari lingkungan dimana ia berada.

Dengan berbagai penjelasan di atas kiranya dapat ditarik sebuah pemahaman bahwa aliran progresivisme merupakan aliran yang ingin menekankan pada sebuah progress. Intelegensi manusia sangat dihargai sebagai salah satu indikator penting dalam pendidikan. Selain itu, faktor lingkungan menjadi amat penting karena nantinya lingkungan itu yang membetuk karakter intelegensi anak didik.

\section{Tinjauan Progresivisme terhadap Kompa- rasi Pendidikan Karakter Ki Hadjar De- wantara dan Driyarkara}

Pendidikan Progresivisme menganggap pendidikan bukanlah hanya menyampaiakan pengetahuan kepada anak didik saja, melainkan yang paling utama adalah melatih kemampuan anak berpikir secara 
ilmiah. Semua itu dilakukan dengan pendidikan supaya orang mengalami progress. Dengan demikian, orang akan bertindak dengan intelegensi sesuai dengan tuntutan dari lingkungan di mana ia berada.

Pendidikan karakter Ki Hadjar Dewantara dan Driyarkara keduanya memiliki kesamaan padangan dan sekaligus perbedaan dalam beberapa hal. Pendidikan karakter menurut Ki Hadjar Dewantara merupakan proses penanaman nilai budi pekerti yang luhur pada anak. Budi pekerti, watak, atau karakter adalah bersatunya gerak pikiran, perasaan dan kehendak atau kemauan, yang kemudian berproses menjadi tenaga. Budi berarti "fikiran, perasaan, kemauan" dan pekerti artinya "tenaga". Jadi, budi pekerti adalah sifatnya jiwa manusia, mulai dari angan-angan hingga terjelma sebagai tenaga. Pendidikan karakter Ki Hadjar Dewantara nampak progresif karena dalam prosesnya mengunakan tiga instrumen dasar, yaitu keluarga, perguruan dan juga pergerakan pemuda.

Anak tidak dijadikan subjek yang pasif melainkan aktif mengembangkan karakternya. Tiga instrumen dasar yaitu keluarga, perguruan dan pergerakan pemuda menjadi dasar instrumen pembentuk budi pekerti (karakter) anak. Keluarga merupakan tahap awal tempat segala hal yang alamiah muncul dan terbentuk, terkait dengan naluri dasariah, mengenai kekalnya keturunan yang menunjukkan bahwa tiaptiap manusia selalu berusaha mendidik anak-anak dengan sesempurna mungkin baik dalam hal rohani maupun jasmani.

Tahap selanjutnya yaitu tahap perguruan tempat mendidik kecerdasan intelektual anak yaitu dalam upayanya mencerdaskan pikiran dan pemberian ilmu pengetahuan. Hal ini bisa dilakukan dengan balai perguruan yang tidak terlepas dari lingkungan keluarga. Artinya, sistem sekolah juga harus berkesinambungan dengan pendidikan dalam keluarga, supaya tidak terjadi keterpisahan pendidikan budi pekerti dan budi kemasyarakatan.

Tahap ketiga yaitu tahap alam pemuda. Tahap ini merupakan tahap tempat pergerakan ini menjadi penyokong teramat besar pada pendidikan, baik dalam kecerdasanjiwa atau budi pekerti, maupun pada kesosialan (Tamansiswa, 2013:74) dalam hal ini pergerakan pemuda membuat anak aktif dan selalu berproses untuk menemukan jati dirinya tanpa lepas dari kontrol orang tua, sehingga kedewasaan anak dalam budi pekerti dan jiwa sosialnya akan terbentuk dengan pergerakan pemuda tersebut.

Tokoh lain yang menekankan progresivisme dalam pendidikan budi pekerti yaitu Driyarkara. Ia menekankan bahwa pendidikan budi pekerti (karakter) bisa dilakukan dengan cara hominisasi dan humanisasi. Hominisasi artinya proses pembentukan manusia secara alamiah dari lahir menuju terbentuknya manusia dewasa, yang tidak kalah penting seiring dengan terbentuknya manusia secara alami yang di sini terjadi proses humanisasi. Humanisasi merupakan tahapan yang lebih tinggi, pada taraf ini manusia pada kodratnya, yaitu taraf insani atau manusiawi, manusia dididik menjadi manusia sebagaimana manusia semestinya.

Menurut Driyarkara pendidikan budi pekerti (karakter) dapat dibentuk dalam kesatuan tri tunggal yaitu ayah-ibu-anak. Bagi manusia berketurunan melahirkan itu tidak hanya secara biologis melainkan juga melahirkan secara insani. Artinya, setelah terjadi proses melahirkan biologis, juga perlu kiranya menlanjutkannya dengan melahirkan secara insani, dalam hal ini membawa anak kepada tingkat manusia. Taraf ini merupakan peletakan karakter dasar 
pada anak. Pada diri ayah-ibu-anak dalam hal ini terjadi ikatan lahir dan batin sehingga tercipta kesatuan yang tidak bisa diganti, sehingga nanti anak akan tumbuh menjadi manusia purnawarman, yang mampu memahami eksistensinya sebagai manusia.

Adapun persamaan dan perbedaan pendidikan karakter Ki Hadjar Dewantara dan Driyarkara sebagai berikut. Pertama, persamaan kedua tokoh ini yaitu terkait dengan peletakan instrumen dasar pendidikan yaitu keluarga sebagai yang paling awal. Ada kesamaan konsep menurut kedua tokoh tersebut bahwa keluarga merupakan peletak dasar budi pekerti (karakter) pada jiwa anak. Sebelum anak mendapat pendidikan pada taraf yang lebih tinggi atau di luar pendidikan keluarga. Pertamatama menurut kedua tokoh ini perlu kiranya keseriusan pendidikan di keluarga ditekankan agar karakter dasar anak terbentuk dengan baik.

Kemudian perbedaanya, Ki Hadjar Dewantara lebih menekankan tiga instrumen dasar yang berkelanjutan, yaitu keluarga, perguruan, dan pergerakan pemu$\mathrm{da}$, karena ketiga instrumen tersebut memiliki peran yang berbeda-beda dalam mengembangkan karakter anak didik. Driyarkara cenderung lebih menekankan instrumen kesatuan aya-ibu-anak sebagai satu kesatuan dasar dalam penanaman karakter dasar pada anak, karena menurutnya jika ayah-ibu-anak sudah menyatu makan akan tercipta suatu keadaan yang membuat anak bisa dengan progresif mengembangkan karakter dasar sekaligus juga penanaman karakter oleh ayah dan ibunya.

Kelebihan dan kekurangan pendidikan karakter Ki Hadjar Dewantara dan Driyarkara sebagai berikut. Kelebihan pendidikan karakter Ki Hadjar Dewantara yaitu adanya kesesuaian yang konsisten dan progresif dalam ketiga tahap perkembangan karakter dasar anak, yang dimulai dari keluarga sebagai peletak dasar karakter, kemudian perguruan sebagai penguat kecerdasan anak sekaligus mengasah karakter anak, dan yang ketiga dalam lingkungan pergerakan pemuda sebagai lahan untuk mengembangkan karakter kesosialan anak. Kekurangan pendidikan karakter Ki Hadjar Dewantara, yaitu sangat sulitnya mengontrol agar ketiga instrumen yang meliputi keluarga, perguruan, dan pergerakan pemuda tetap konsisten. Tetapi jika ketiganya bisa konsisten akan berdampak baik pada karakter anak didik.

Kelebihan pendidikan karakter Driyarkara, yaitu Driyarkara mencoba untuk menggunakan progresivitas ikatan ayahibu-anak sebagai dasar dalam membentuk karakter dasar anak. Karena dengan adanya ikatan yang kuat antara ayah-ibu-anak akan tercipta suatu keserasian yang membuat anak mampu mengembangkan potensi dasar yang ada pada dirinya, kemudian ayah-ibu akan menjadi alat kontrol yang tepat terhadap anak didiknya. Tugas ayahibu mengawasi dan menanamkan nilainilai keteladanan pada diri anak. Kekuranganya, Driyarkara cenderung menekankan aspek keluarga dan kurang memperhatikan aspek sosial, dan kepemudaan sebagaimana Ki Hadjar Dewantara. Karena pada dasarnya karakter juga bisa terbentuk tidak hanya melalui instrumen keluarga saja, masih ada instrumen lain yang berperan seperti masyarakat dan organisasi sosial lainya.

Pendidikan karakter Ki Hadjar Dewantara dan Driyarkara kiranya relevan dengan pendidikan di Indonesia apabila dipadukan sebagai upaya penanaman pendidikan karakter di dalam masyarakat Indonesia (Nova, 2017). Dengan memulai dari lingkungan keluarga karakter dasar masyarakat Indonesia akan terbentuk, setelah 
lingkungan keluarga dan selanjutnya beralih pada lingkungan sekolah. Di dalam lingkungan sekolah karakter anak tersebut akan terasah dan bertambah dengan adanya pendidikan dari guru. Setelah lingkungan sekolah, pendidikan karakter kemudian beralih pada lingkungan pergerakan pemuda. Di sanalah jiwa karakter anak akan teruji dan terbentuk sesuai dengan kemampuan dan kemauan anak didik.

\section{PENUTUP}

Berdasarkan uraian hasil dan pembahasan di atas dapat disimpulkan, Ki Hadjar Dewantara menjelaskan bahwa budi pekerti atau watak yaitu bulatnya jiwa manusia, yang dalam bahasa asing disebut "karakter" sebagai jiwa yang berasas hukum kebatinan. Orang yang telah mempunyai kecerdasan budi pekerti senantiasa memikirkan dan merasakan serta memakai ukuran, timbangan, dan dasar yang pasti dan tetap. Menurut Ki Hadjar Dewantara pendidikan karakter dapat ditempuh melalui trisentra karena di dalam kehidupan anak-anak ada tiga tempat pergaulan yang menjadi pusat pendidikan yang amat penting baginya yaitu alam keluarga, alam perguruan, dan alam pergerakan pemuda.

Adpaun menurut Driyarkara pendidikan karakter merupakan proses hominisasi dan humanisasi sebagai proses pendidikan karakter. Proses hominisasi yaitu proses kemenjadian manusia secara alami. Hominisasi tidak pernah lepas dari humanisasi. Humanisasi biasanya merujuk pada perkembangan yang lebih tinggi. Jikalau hanya mengingat arti kata human, berarti sesuai dengan kodrat manusia, sehingga sama dengan insani atau manusiawi. Pada tingkat humanisasi, pendidikan karakter yang paling fundamental dapat dibentuk dalam kesatuan tritunggal yaitu ayah-ibuanak. Pendidikan karakter dalam hal ini terjadi dalam proses tritunggal itu dari menyatunya ayah-ibu-anak sampai pada taraf purnawarman, yaitu pada saat karakter anak terbentuk ia mampu memahami dirinya sendiri sebagaimana ia menjadi manusia pada umumnya yang bebas dan bertanggung jawab.

Pendidikan karakter Ki Hadjar Dewantara dan Driyarkara kiranya relevan dengan pendidikan di Indonesia apabila dipadukan sebagai upaya penanaman pendidikan karakter di dalam masyarakat Indonesia. Ini dimulai dari lingkungan keluarga sebagai peletak karakter dasar, kemudian lingkungan sekolah atau perguruan sebagai tempat melatih intelektual sosial, dan juga pergerakan pemuda sebagai ajang menampilkan karakter anak didik sekaligus tempat mencetak karakter anak didik dengan tidak meninggalkan kontrol dari sang pendidik.

\section{UCAPAN TERIMA KASIH}

Dengan mengucap Alhamdulillah penulis bersyukur kepada Allah SWT. atas rahmat dan hidayah-Nya sehingga penulis dapat menyelesaikan artikel ini. Tidak lupa penulis mengucapkan terima kasih kepada semua pihak yang telah membantu kelancara penulisan artikel ini. Terutama kepada seluruh jajaran anggota Dewan Redaksi Jurnal Pendidikan Karakter. Semoga Allah senantiasa memberikan berkah-Nya di dunia dan di akhirat kelak.

\section{DAFTAR PUSTAKA}

Ali, H. (1990). Filsafat pendidikan. Yogyakarta: Kota Kembang.

Aziz, A.RA. (2016). Konsep hominisasi dan humanisasi menurut Driyarkara. ALA'RAF: Jurnal Pemikiran Islam dan Filsafat, 13(1), 127-148. DOI: 10.22515/ajpif.v13i1.39. 
Bakker \& Zubair. (1990). Metodologi penelitian filsafat. Yogyakarta: Kanisius.

Barnadib, I. (1982). Filsafat pendidikan. Yogyakarta: Kanisius.

(1992). Pendidikan perbandingan. Yogyakarta: Gunung Agung.

Driyarkara, (1980). Driyarkara tentang pendidikan. Yogyakarta: Kanisius.

Husaini, A. (2010). Pendidikan karakter: penting, tapi tidak cukup! Bogor: Program Pascasarjana Universitas Ibnu Khaldun.

Idris, R. (2017). Perubahan sosial budaya dan ekonomi Indonesia dan pengaruhnya terhadap pendidikan. Lentera Pendidikan: Jurnal Ilmu Tarbiyah dan Keguruan, 14(2), 219-231. DOI: 10.24252/lp.2011v14n2a7.

Jalaluddin \& Idi, A. (2012). Filsafat pendidikan: Manusia, filsafat dan pendidikan. Jakarta: Rajawali Press.

Ningrum, D. (2015). Kemerosotan moral di kalangan remaja: Sebuah penelitian mengenai parenting styles dan pengajaran adab. UNISIA: Jurnal Ilmu-ilmu Sosial, 37(82), 18-30. Diunduh dari: https://journal.uii.ac.id/Unisia/articl e/view/10491/8171.
Ningsih, T. (2015). Implementasi pendidikan karakter. Purwokerto: STAIN Press.

Nova, M. (2017). Pendidikan karakter di kelas EFL Indonesia: Implementasi dan hambatan. Jurnal Pendidikan Karakter, 7(2), 142-157. DOI: 10.21831/jpk.v7i2.13650.

Pratyanto, R.N. (31 Juli 2017). Biografi singkat Prof. Dr. N. Driyarkara, SJ. Diambil pada tanggal 11 Juni 2019, dari http://www.driyarkara.ac.id/index.p hp/component/k2/item/55-biografisingkat-prof-dr-n-driyarkara-sj.

Suparlan, H. (2015). Filsafat pendidikan Ki Hadjar Dewantara dan sumbanganya bagi pendidikan di Indonesia. Jurnal Filsafat, 24(1), 56-74. DOI: 10.22146/jf.12614.

Suroso. (2011). Pemikiran Ki Hadjar Dewantara tentang belajar dan pembelajaran. Scholaria, 1(1), 46-72.

Tamansiswa, M.L. (2013). Ki Hadjar Dewantara: Pemikiran, konsepsi, keteladanan, sikap merdeka Jilid 1. Yogyakarta: USTPress.

Zainuddin. (2008). Reformasi pendidikan: kritik kurikulum dan managemen berbasis sekolah. Yogyakarta: Pustaka Pelajar. 